\title{
Differences in the accuracy of potato dextrose agar and CHROMagar media in diagnosing oral candidiasis
}

\author{
Hyun-Jeong Park ${ }^{1 \dagger}$, Ji Hoo Kim², and Ji-Won Ryu ${ }^{3 *}$ \\ ${ }^{1}$ Clinical Professor, Department of Oral Medicine, Chosun University Dental Hospital, Gwangju, Republic of Korea \\ ${ }^{2} \mathrm{Ph} . \mathrm{D}$. Student, Department of Oral Medicine, College of Dentistry, Chosun University, Gwangju, Republic of Korea \\ ${ }^{3}$ Professor, Department of Oral Medicine, College of Dentistry, Chosun University, Gwangju, Republic of Korea
}

For the diagnosis of oral candidiasis, the most commonly used method is culturing the Candida strains acquired by rubbing the mucous membrane in the mouth using a sterile cotton swab on the medium. This study was conducted to compare the accuracy of Potato Dextrose Agar (PDA) and chromogenic CHROMagar media in diagnosing oral candidiasis. This study included patients diagnosed with oral candidiasis who visited Chosun University Dental Hospital between January 1, 2018 and February 28, 2019. All study subjects were tested using the culture method to diagnose oral candidiasis. For statistical analysis of this study, IBM SPSS version 25.0 (IBM Co., Armonk, NY, USA) was used. Cross analysis was used to compare the diagnostic accuracy of PDA and CHROMagar media as well as treatment effects and diagnoses using each medium. When diagnosed using PDA medium, the sensitivity was high at $91.3 \%$ but the specificity was relatively low at $46.0 \%$. It was observed that the accuracy of the diagnosis method using PDA medium was relatively lower than that of the diagnosis method using CHROMagar medium. But the treatment effects in groups diagnosed with PDA medium were higher than those diagnosed with CHROMaga medium. According to the results of our study, CHROMagar medium is recommended for the diagnosis of oral candidiasis; as an alternative, a nonselective medium, such as PDA medium, can be used for the diagnosis of oral candidiasis.

Key Words: Chromogenic; Diagnosis; Oral candidiasis; Potato dextrose agar

(c) This is an open-access article distributed under the terms of the Creative Commons Attribution Non-Commercial License (http://creativecommons.org/licenses/by-nc/4.0) which permits unrestricted noncommercial use, distribution, and reproduction in any medium, provided the original work is properly cited.

\section{Introduction}

구강 칸디다증은 주로 칸디다 균종의 기회감염에 의해 발생 되는 질환이다[1,2]. 구강 칸디다증을 일으키는 칸디다 균종 은 다양하다[1]. 가장 대표적인 균은 Candida albicans로 구강 내 단독으로 존재하기도 하고 Candida glabrata or Candida tropicalis과 함께 존재하기도하며, 최근에 발견된 Candida dubliniensis도 있다[1,2]. 이들은 대개 구강 내 상주균으로 일 반적으로는 구강 내 불편감을 야기하지 않는다[1]. 그러나 면역 계 이상이나 구강 내 균총의 변화를 야기하는 약물치료 등으로 인해 구강 칸디다증으로 진행될 수 있다[1,3]. 구강 칸디다증은 증상의 발생시기에 따라 급성 또는 만성으로 나눌 수 있다[1].

구강 칸디다증의 기여 요인으로는 당뇨, 임신, 신부전 등에 의 한 내분비계의 변화, 항생제 및 스테로이드 등의 장기간의 약물

Received June 13, 2021; Revised July 15, 2021; Accepted July 22, 2021

*Corresponding author: Ji-Won Ryu, Department of Oral Medicine, School of Dentistry, Chosun University, 309 Pilmun-daero, Dong-gu, Gwangju 61452, Republic of Korea.

Tel: +82-62-220-3897, Fax: +82-62-234-2119, E-mail: dentian@chosun.ac.kr

${ }^{\dagger}$ Current affiliation: Assistant Professor, Department of Oral Medicine, College of Dentistry, Chosun University, Gwangju, Republic of Korea 
치료 및 방사선치료, 쇼그렌 증후군과 같은 자가면역질환 등에 의한 구강건조증, 잘못된 의치의 사용, HIV 등의 면역계 질환 등 이 있다[4]. 일반적으로 구강 칸디다증의 임상 증상은 뚜렷하기 때문에 임상가들이 감별하기에 비교적 용이하다[1,5]. 그러나 간혹 증상이 경미한 경우나 만성인 경우 다른 구강점막질환과 의 감별이 쉽지 않다[1]. 최근 노인 인구의 증가로 인해 전신질 환의 증가, 약물사용의 증가 및 의치 사용이 증가하면서 만성 구 강 칸디다증이 증가하는 추세이다[6]. 그러므로 정확한 진단이 이루어진다면 치료 기간을 단축시킬 수 있다는 점에서 진단은 매우 중요한 문제이다[4].

구강 칸디다증의 감별진단을 위해 사용되는 검사는 여러 가 지가 있다[7]. 주로 사용되는 방법은 미생물 배양법으로 cotton $\mathrm{swab}$ 을 이용하여 구강 내 점막을 문질러 획득한 균을 배지에 배양하는 방식이다[8]. 그 외에도 Polymerase chain reaction (PCR), Enzyme-linked immunosorbent assay 등의 분자생물 학적 방법을 이용하여 진단할 수도 있다[8]. 그러나 후자의 경우 고가의 장비도 필요하고 고도의 기술적인 요소들이 요구되어 일반 의료기관에서 상용화하기에 어렵다[8]. 반면 미생물 배양 법은 검사 방법이 간단하고 환자 편이성이 뛰어나 흔히 사용된 다[9,10]. 이때 사용되는 배지는 다양하다[9]. 흔히 진균을 배양 하기 위해 사용되는 것으로는 비 선택적인 배지로 Potato Dextrose Agar (PDA) 배지, Sabroud Dextrous Agar (SDA) 배지 및 칸디다 균종의 선택배지인 CHROMagar 배지 등이 있다[9]. 이 연구는 비 선택 배지인 PDA 배지와 칸디다 균종의 선택 배지인 CHROMagar의 칸디다 진단의 정확도를 평가하기 위해 시행하 였다.

\section{Materials and Methods}

\section{Subjects}

본 연구는 2018년 1월 1일부터 2019년 2월 28일까지 조선 대학교 치과병원에 내원하여 구강 칸디다증으로 진단된 환자들 을 대상으로 하였다. 모든 환자들은 문진, 임상검사 및 칸디다균 배양검사를 시행하였다. 문진 검사상에는 전신질환, 약물복용, 증상이 발생하기 시작한 시기 등의 항목을 포함하고 있다. 구강 칸디다증 이외에 다른 연조직 질환을 가지고 있는 환자들은 연 구대상에서 제외되었다. 본 연구는 조선대학교 임상윤리위원회 의 심의를 통과하였다(IRB no. CUDHIRB 1703 011).

\section{Procedure}

모든 연구 대상은 처음 내원 시 칸디다균 배양검사를 시행하
였다. 배양검사 방법은 cotton swab을 이용하여 환자의 구강 점막을 문질러 이를 배지에 도말하는 방식을 이용하였다. 이때 사용된 배지는 비 선택배지인 PDA 배지(Kisan Bio Co., Ltd., Seoul, Korea)와 칸디다 균주의 선택배지인 CHROMagar 배지 (CONDA; Department of Oral Medicine, Chosun University Dental Hospital, Gwangju, Korea)를 이용하였다. 도말된 배 지들은 24-48시간 동안 $37^{\circ} \mathrm{C}$ 항온수조(Kukje Inc. Co., Ltd., Goyang, Korea)에서 배양되었다. 배양이 끝난 배지에서 콜로니 가 형성되는 경우 칸디다증으로 진단되었다.

\section{Statistical analysis}

이 연구의 통계 분석은 IBM SPSS, version 25.0 (IBM Co., Armonk, NY, USA)를 이용하였다. 환자 분포에 따른 연령, 성 별, 증상 발생 시점 등에 관한 통계는 비율(\%)과 평균土표준편 차(mean \pm standard deviation)로 나타내었다. PDA 배지와 CHROMagar 배지를 이용한 진단의 정확성 비교, 각 배지를 이 용한 진단과 치료 효과 간의 비교에서는 교차분석을 이용하였다.

\section{Results}

본 연구의 환자분포를 살펴보면 전체 환자 수는 216 명으로 이중 여성은 156 명(77.2\%) 남성은 60명(27.8\%)으로 여성이 우 세하였다(Table 1). 평균 연령은 $66.2 \pm 14.2$ (여성의 평균연령 은 $66.5 \pm 13.6$, 남성의 평균연령은 $65.5 \pm 15.8$ )으로 나타났다 (Table 1). 해당 기간 동안 내원한 환자들에서는 증상이 시작된 시점에서 병원에 내원하기까지 걸린 시간을 살펴볼 때, 1 달 이 내에 내원한 환자 수가 60 명으로 전체의 $27.8 \%$ 를 차지하는 반 면 3개월 이상의 시간이 경과된 환자 수는 136 명으로 전체의 63.0\%이다(Table 1). 이는 환자들의 증상이 만성으로 전환된 이

Table 1. Demographic characteristics of the subject

\begin{tabular}{clc}
\hline & Characteristic & Patient \\
\hline Sex & Male & $60(27.8)$ \\
& Female & $156(77.2)$ \\
\multirow{3}{*}{ Age } & Total & $216(100)$ \\
& Male & $65.5 \pm 15.8$ \\
\multirow{2}{*}{ Onset } & Female & $66.5 \pm 13.6$ \\
& Total & $66.2 \pm 14.2$ \\
& $\mathrm{D}<1 \mathrm{M}$ & $63(29.2)$ \\
& $1 \mathrm{M} \leq \mathrm{D}<3 \mathrm{M}$ & $21(9.7)$ \\
& $\mathrm{D} \geq 3 \mathrm{M}$ & $132(61.1)$ \\
\hline
\end{tabular}

Values are presented as number (\%) or mean \pm standard deviation. $\mathrm{D}$, duration; $\mathrm{M}$, month. 
후에 발생되는 환자 수가 상당 부분을 차지한다고 볼 수 있다 (Table 1).

본 연구에서 구강 칸디다증을 진단하기 위해 사용된 두 배 지 간의 진단학적 정확도를 분석해 보았다. 이미 많은 연구들에 서 CHROMagar 배지의 민감도 및 특이도는 모두 $90 \%$ 이상이 다[11-13]. 그리하여 우리 연구에서는 이러한 결과들을 바탕으 로 $\mathrm{PDA}$ 배지를 이용한 칸디다증 진단의 정확도를 살펴보았다 (Table 2). 본 연구에서는 CHROMagar 배지를 이용한 구강 칸 디다증 진단과 $\mathrm{PDA}$ 배지를 이용한 구강 칸디다증 진단을 교차 분석을 통해 분석하였다(Table 2). PDA 배지를 이용한 구강 캔 디디다증 진단의 민감도(sensivity)는 $91.3 \%$ 로 높으나 특이도 (specificity)가 46.0\%로 비교적 낮게 나왔다(Table 2). 이는 상 대적으로 $\mathrm{CHROMagar}$ 배지를 이용한 진단법보다 PDA 배지를 이용한 진단법이 좀 더 정확도가 떨어진다고 볼 수 있다. 구강 칸디다증으로 진단된 환자군에 Diflucan dry syrup $350 \mathrm{mg} / 35$ mL (10 mg/mL) (Pfizer Pharmaceutical Korea, Seoul, Korea) 와 같은 항진균제를 이용하여 치료를 시행했을 때, 각 배지로 진 단한 결과와 항진균제의 치료효과를 교차분석을 이용해 분석 하였다(Table 3). 그 결과 $\mathrm{PDA}$ 배지를 이용한 진단의 민감도가
CHROMagar 배지를 이용한 것보다 높은 반면, 특이도는 낮았 다(Table 3).

\section{Discussion}

최근 노인 인구가 증가함에 따라 구강 내 부적절한 의치 사용, 다양한 전신질환에 따른 구강 건조, 면역계 이상 등의 문제 및 항생제, 소염제 등의 약물사용 증가 등의 이유로 칸디다증의 유 병률이 증가하는 추세이다[6]. 본 연구에서도 환자들의 분포를 보면 평균 연령이 66.2 1 14.2세로 높게 나타났다(Table 1). 노 인들이 비중이 늘어나면서 앞으로 더욱 유병률이 증가할 것으 로 예상할 수 있다[6]. 또한, 구강 칸디다증은 대부분 경증으로 항진균제를 사용하면 상당히 회복 가능하다[14]. 그러나 재발이 빈번하며 재발이 될수록 항진균제의 내성이 발생하게 되면 점 차 만성적으로 나타나게 된다[14]. 본 연구에서도 증상이 3개월 이상 지속되고 있는 환자의 비율이 전체의 $63.0 \%$ 로 높게 나타 나고 있다(Table 1). 심지어 급성뿐만 아니라 만성적으로 지속 되는 구강 칸디다증은 구강 내에만 국한된 것이 아니라 전신에 파급될 수 있다는 위험이 있다[1,15]. 따라서 구강 칸디다증의

Table 2. Sensitivity and specificity of diagnosis using PDA comparing with CHROMagar medium

A. The culture result of PDA medium and CHROMagar medium

\begin{tabular}{|c|c|c|c|c|}
\hline \multirow{2}{*}{\multicolumn{2}{|c|}{$\begin{array}{l}\text { Cross tab analysis between } \\
\text { PDA and CHROMagar medium }\end{array}$}} & \multicolumn{2}{|c|}{ CHROMagar medium } & \multirow{3}{*}{$\begin{array}{r}\text { Total } \\
160\end{array}$} \\
\hline & & \multirow{2}{*}{$\begin{array}{c}\text { Positive } \\
106\end{array}$} & \multirow{2}{*}{ Negative } & \\
\hline PDA medium & Positive & & & \\
\hline & Negative & 10 & 46 & 56 \\
\hline \multicolumn{2}{|c|}{ Total } & 116 & 100 & 216 \\
\hline
\end{tabular}

B. Sensitivity and Specificity of diagnosis using PDA medium comparing with CHROMagar medium

$\begin{array}{ll}\text { Sensitivity (\%) } & 91.4 \\ \text { Specificity (\%) } & 46.0\end{array}$

Values are presented as number.

PDA medium, Potato Dextrose Agar medium.

Table 3. Relation of culture medium and treatment effect

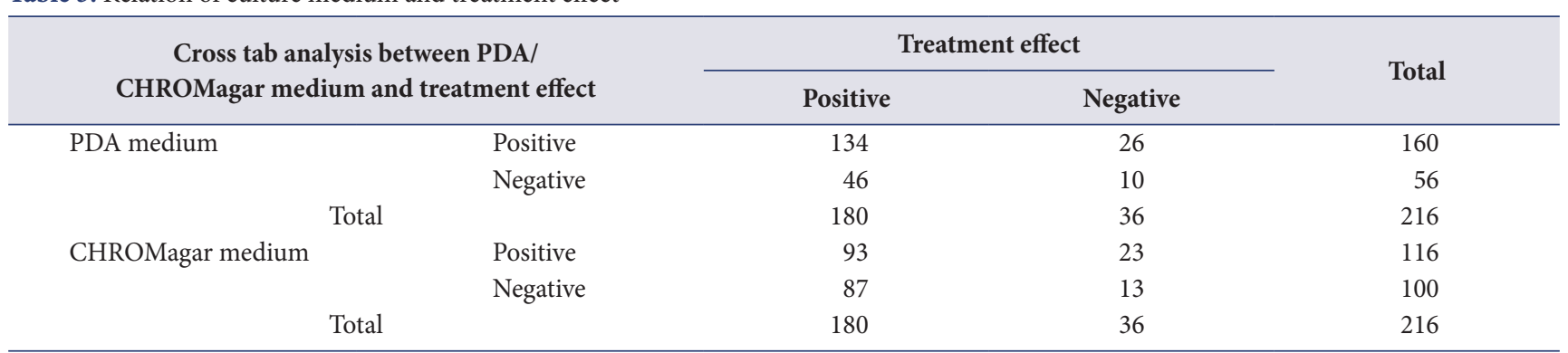

Values are presented as number.

PDA medium, Potato Dextrose Agar medium. 
신속하고 정확한 진단이 무엇보다도 중요하다[1,15].

구강 칸디다증의 진단 방법에는 여러 가지가 있다[8,15,16]. 이 균종이 어떤 것인지 정확히 감별하기 위해서는 균종에 대 한 전기영동 및 PCR 등의 분자 생물학적 방법을 이용해야 한 다[17]. 그러나 PCR을 시행하기 위해서는 분석을 위한 장비 가 필요하며 배양법에 비해 방법이 복잡하고 비용도 많이 든다 [15,17]. 그러나 흔히 임상에서 이용하는 미생물 배양법은 간편 하고 비용이 저렴하여 사용이 용이하다[18]. 미생물을 배양하 는 배지의 종류는 다양하며 감별하고자 하는 미생물에 따라 선 택이 가능하다[18]. 일반적으로 사용되는 비선택적 배지인 PDA 배지와 $\mathrm{SDA}$ 배지는 진균을 배양하기 적당한 배지로 배양이 잘 된다[15]. 이는 전반적인 효모를 배양하기 적절한 배지로 효모 를 증식하기 위해 사용된다[15]. 그러한 이유로 매우 소량의 효 모도 배양된다는 장점이 있다[19]. 그러나 배양된 효모가 어떤 특정 균종인지를 바로 알 수는 없다[19]. 단지, 일반적으로 구강 내 상주하는 균의 유무 정도만 파악할 수 있다고 볼 수 있다[19]. $\mathrm{PDA}$ 배지는 대개 콜로니가 크림색을 띄며 일부 짙은 색이 나타 나기도 하기 때문에 색깔로 구별하기는 어렵고 콜로니의 크기, 질감 등을 이용해 감별해야 하기 때문이다(Fig. 1) [19]. 반면 칸 디다 선택 배지인 CHROMagar 배지의 경우 일반적으로 칸디다 종이 주로 배양된다[12]. 또한, 이 배지는 칸디다종 내 하부 종을 색깔로 구별해낼 수 있다(Fig. 1). CHROMagar의 경우 C. albicans는 Apple green, $C$. dubliniensis 는 Dark green, $C$. rugosa 는 Green, $C$. glabrata는 Lavender, $C$. krusei는 Pink velvet, $C$. tropicalis 는 Metallic blue, C. parapsilosis는 Pink/Light pink 로 나타난 $[15,20,21]$. 이러한 CHROMagar 배지에 배양된 콜로 니의 색깔의 차이는 칸디다 균종의 하부 종을 특정할 수 있게 되 고 이로 인해 치료기간 및 치료 방법을 선택하는데 도움이 된다 [19]. 이러한 이유로 구강 내 상주균인 칸디다종을 동정하기 위 해서는 CHROMagar 배지에 우선적으로 고려되는 것이 좋다 $[12,19]$. 본 연구에서도 CHROMagar 배지와 비교했을 때 PDA 배지의 경우 민감도는 비교적 높은 편이나 특이도가 매우 낮고 정확도가 낮았다(Table 2). 본 연구에서는 구강 칸디다증의 임
상증상이 존재하며 PDA 배지에는 배양이 되지만 CHROMagar 배지에서는 배양이 되지 않는 경우들이 있었다(Table 2). 그러 나 이런 환자들에게 Diflucan dry syrup $350 \mathrm{mg} / 35 \mathrm{~mL}$ (10 $\mathrm{mg} / \mathrm{mL}$ ) (Pfizer Pharmaceutical Korea)와 같은 항진균제를 국 소적으로 적용 후 치료 효과를 분석한 결과, $\mathrm{PDA}$ 배지를 이용 한 것이 CHROMagar 배지를 이용한 경우보다 더 높았다(Table 3). 이것은 $\mathrm{PDA}$ 배지가 민감도가 높기 때문에 구강 내 아주 적 은 농도의 칸디다균이라도 배양이 된 것으로 여겨진다(Table 3). 구강 칸디다증의 치료에 사용되는 진균제는 다양한 종류가 존재한다[1,22]. 그 중에서도 본 연구에서 사용된 항진균제인 Diflucan dry syrup은 Azole계의 fluconazole로 이는 수용성이 며 구강 점막에 잘 부착되어 다른 약제보다 흡수가 잘 되는 장 점 때문에 구강 칸디다증 치료에 효과적인 약물이다[1,22]. 항 진균제는 약제마다 오랫동안 사용하면 내성으로 인해 치료효과 가 떨어질 수 있다[1,22]. Fluconazole같은 경우에도 다른 약제 에 비해서는 약물 내성이 약하지만 존재하므로 주의하여 사용 해야 한다[1,22]. 본 연구에서도 PDA 배지에서 양성을 보임에도 fluconazole에 의한 치료효과가 떨어지는 경우가 $12.0 \%$ 였고, CHROMagar 배지에서는 10.7\%로 확인되었다(Table 3).

우리 연구에서는 구강 칸디다 진단을 위해 CHROMagar 배지 를 우선적으로 사용하는 것을 추천하나 CHROMagar 배지를 사 용할 수 없는 환경에서는 PDA 배지와 같은 비선택배지도 보조 적으로 구강 칸디다증 진단에 도움을 줄 수 있다는 것을 확인하 였다. 본 연구에서는 정확한 구강 칸디다증 진단을 위해 사용되 는 분자 생물학적 방법을 이용하지는 않았다. 배양법 간의 정확 도 비교만 시행한 것으로 이로 인해 진단학적 오차가 존재한다. 추가적인 연구에서는 분자 생물학적 방법을 이용한 진단법, 현 미경 상 균주 확인 등의 진단법을 추가하여 비교한다면 좀 더 신 뢰할만한 진단학적 차이를 알 수 있을 것으로 여겨진다.

\section{Acknowledgements}

This study was supported by research fund from Chosun
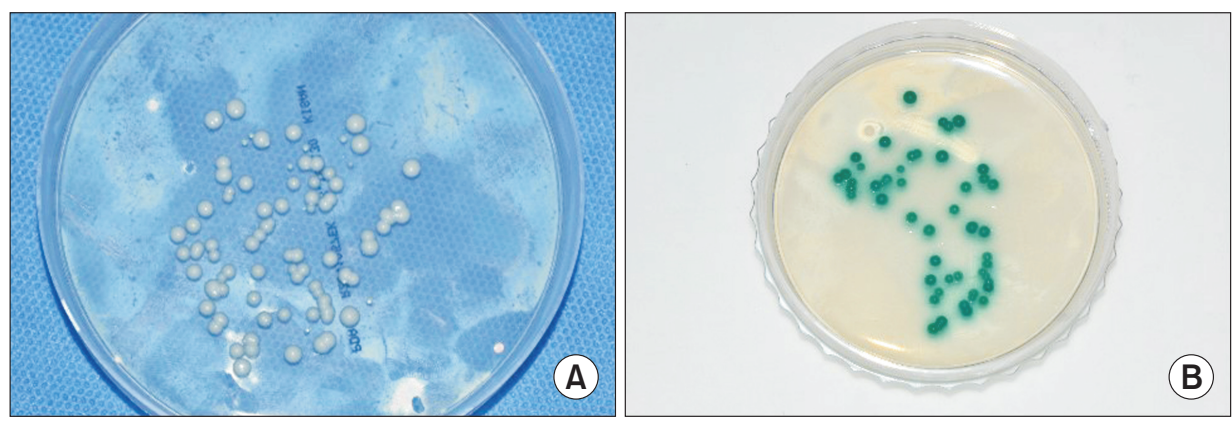

Fig. 1. (A) PDA medium. The white colony was cultured on PDA medium for 48 hours in an incubator at $37^{\circ} \mathrm{C}$. (B) CHROMagar medium. The green colony was cultured on CHROMagar medium for 48 hours in an incubator at $37^{\circ} \mathrm{C}$.

PDA medium, Potato Dextrose Agar medium. 
University Dental Hospital, 2019.

\section{Conflicts of Interest}

The authors declare that they have no competing interests.

\section{ORCID}

\author{
Hyun-Jeong Park \\ https://orcid.org/0000-0002-5237-005X \\ Ji Hoo Kim \\ https://orcid.org/0000-0002-0669-3309 \\ Ji-Won Ryu \\ https://orcid.org/0000-0002-5586-8195
}

\section{References}

1. Akpan A, Morgan R. Oral candidiasis. Postgrad Med J 2002;78:455-459. doi: 10.1136/pmj.78.922.455.

2. Dadar M, Tiwari R, Karthik K, Chakraborty S, Shahali Y, Dhama K. Candida albicans - biology, molecular characterization, pathogenicity, and advances in diagnosis and control - an update. Microb Pathog 2018;117:128-138. doi: 10.1016/j.micpath.2018.02.028.

3. Nadeem SG, Hakim ST, Kazmi SU. Use of CHROMagar Candida for the presumptive identification of Candida species directly from clinical specimens in resource-limited settings. Libyan J Med 2010;5:2144. doi: 10.3402/ljm. v5i0.2144.

4. Coronado-Castellote L, Jiménez-Soriano Y. Clinical and microbiological diagnosis of oral candidiasis. J Clin Exp Dent 2013;5:e279-e286. doi: 10.4317/jced.51242.

5. Nakamura S, Okamoto MR, Yamamoto K, Tsurumoto A, Yoshino Y, Iwabuchi H, Saito I, Maeda N, Nakagawa Y. The Candida species that are important for the development of atrophic glossitis in xerostomia patients. BMC Oral Health 2017;17:153. doi: 10.1186/s12903-017-0449-3.

6. Flevari A, Theodorakopoulou M, Velegraki A, Armaganidis A, Dimopoulos G. Treatment of invasive candidiasis in the elderly: a review. Clin Interv Aging 2013;8:1199-1208. doi: 10.2147/CIA.S39120.

7. Candel FJ, Pazos Pacheco C, Ruiz-Camps I, Maseda E, Sánchez-Benito MR, Montero A, Puig M, Gilsanz F, Aguilar J, Matesanz M. Update on management of invasive candidiasis. Rev Esp Quimioter 2017;30:397-406.

8. Safavieh M, Coarsey C, Esiobu N, Memic A, Vyas JM, Shafiee $\mathrm{H}$, Asghar W. Advances in Candida detection platforms for clinical and point-of-care applications. Crit Rev Biotechnol 2017:37:441-458. doi: 10.3109/07388551.2016.1167667.
9. Houang ET, Chu KC, Koehler AP, Cheng AF. Use of CHROMagar Candida for genital specimens in the diagnostic laboratory. J Clin Pathol 1997;50:563-565. doi: 10.1136/ jcp.50.7.563.

10. Ainscough S, Kibbler CC. An evaluation of the costeffectiveness of using CHROMagar for yeast identification in a routine microbiology laboratory. J Med Microbiol 1998;47:623-628. doi: 10.1099/00222615-47-7-623.

11. Devi LS, Maheshwari M. Speciation of Candida species isolated from clinical specimens by using Chrom agar and conventional methods. Int J Sci Res Publ 2014;4:1-5.

12. Yücesoy M, Marol S. Performance of CHROMAGAR candida and BIGGY agar for identification of yeast species. Ann Clin Microbiol Antimicrob 2003;2:8. doi: 10.1186/14760711-2-8.

13. Ainscough S, Kibbler CC. An evaluation of the costeffectiveness of using CHROMagar for yeast identification in a routine microbiology laboratory. J Med Microbiol 1998;47:623-628. doi: 10.1099/00222615-47-7-623.

14. Garcia-Cuesta C, Sarrion-Pérez MG, Bagán JV. Current treatment of oral candidiasis: a literature review. J Clin Exp Dent 2014;6:e576-e582. doi: 10.4317/jced.51798.

15. Sahand IH, Maza JL, Eraso E, Montejo M, Moragues MD, Aguirre JM, Quindós G, Pontón J. Evaluation of CHROMPal medium for the isolation and direct identification of Candida dubliniensis in primary cultures from the oral cavity. J Med Microbiol 2009;58(Pt 11):1437-1442. doi: 10.1099/jmm.0.011320-0.

16. Souza MN, Ortiz SO, Mello MM, Oliveira Fde M, Severo LC, Goebel CS. Comparison between four usual methods of identification of Candida species. Rev Inst Med Trop Sao Paulo 2015;57:281-287. doi: 10.1590/S003646652015000400002.

17. Jafari Z, Motamedi M, Jalalizand N, Shokoohi GR, Charsizadeh A, Mirhendi H. Comparison of CHROMagar, polymerase chain reaction-restriction fragment length polymorphism, and polymerase chain reaction-fragment size for the identification of Candida species. Curr Med Mycol 2017:3:10-15. doi: 10.29252/cmm.3.3.10.

18. Hulimane S, Maluvadi-Krishnappa R, Mulki S, Rai H, Dayakar A, Kabbinahalli M. Speciation of Candida using CHROMagar in cases with oral epithelial dysplasia and squamous cell carcinoma. J Clin Exp Dent 2018;10:e657-e660. doi: 10.4317/jced.54737.

19. Madhavan P, Jamal F, Chong PP, Ng KP. Identification of local clinical Candida isolates using CHROMagar Candida ${ }^{\mathrm{TM}}$ as a primary identification method for various Candida species. Trop Biomed 2011;28:269-274.

20. Lewis MAO, Williams DW. Diagnosis and management of oral candidosis. Br Dent J 2017;223:675-681. doi: 10.1038/ sj.bdj.2017.886.

21. Murray MP, Zinchuk R, Larone DH. CHROMagar Candida as the sole primary medium for isolation of yeasts and as 
a source medium for the rapid-assimilation-of-trehalose test. J Clin Microbiol 2005;43:1210-1212. doi: 10.1128/ JCM.43.3.1210-1212.2005.

22. Goins RA, Ascher D, Waecker N, Arnold J, Moorefield
E. Comparison of fluconazole and nystatin oral suspensions for treatment of oral candidiasis in infants. Pediatr Infect Dis J 2002;21:1165-1167. doi: 10.1097/00006454200212000-00017. 